\title{
The Effect of Noni Fruit Extract (Morinda citrifolia L.) in Gingivitis Patient
}

\author{
Yufri Aldi ${ }^{1 * *}$, Hasanatul Khairiyah ${ }^{1}$, Nila Kasuma ${ }^{2}$, Afriwardi $^{3}$, Agus Sri Banowo ${ }^{4}$
}

Yufri Aldi ${ }^{1, *}$, Hasanatul

Khairiyah ${ }^{1}$, Nila Kasuma ${ }^{2}$, Afriwardi ${ }^{3}$, Agus Sri Banowo ${ }^{4}$

'Department of Pharmacology, Faculty of Pharmacy, Universitas Andalas, Padang, INDONESIA.

${ }^{2}$ Departemen Oral Biology, Faculty of Dentistry, Universitas Andalas, Padang, INDONESIA.

${ }^{3}$ Department Physiology Medicine, Faculty of Medicine, Universitas Andalas, Padang, INDONESIA.

${ }^{4}$ Department Mental Health and Community Nursing, Faculty of Nursing, Universitas Andalas, Padang, INDONESIA.

\section{Correspondence}

Dr. Yufri Aldi, M.Si., Apt.

Department of Pharmacology, Faculty of Pharmacy, Universitas Andalas, Padang, 25163, INDONESIA

E-mail: yufrialdi@phar.unand.ac.id

History

- Submission Date: 29-11-2018;

- Review completed: 16-04-2019.

- Accepted Date: 28-04-2019.

DOI : 10.5530/pj.2019.11.107

Article Available online

http://www.phcogj.com/v11/i4

Copyright

(C) 2019 Phcogj.Com. This is an open access article distributed under the terms of the Creative Commons Attribution 4.0 International license.

\begin{abstract}
Introduction: Antiseptic mouthwash (chlorhexidine and povidone iodine) is usually used to decrease the number of colonies of pathogenic bacteria. But, somehow it gives side effect if it used for a long time. So, it should take another alternative as a raw material to make a mouthwash with minimal side effects, economical and efficacious. Aim: The aim of this research was to examine the effect of noni fruit extract (Morinda citrifolia L.) that given as mouthwash on 15 gingivitis patients. Materials and Methods: The research was conducted for 7 days in a row and gingival index of each patient was measured before and after the treatment. The patients were divided into 3 group and given 3 different treatments. Group I used mouthwash noni fruit extract 5\%; Group II used chlorhexidine 0.1\%; and Group III used a mixture of extracts of noni: chlorhexidine (2.5\%: $0.05 \%)$. The mouthwash was used in the morning and at the night before going to sleep as much as $15 \mathrm{ml}$ and gargling it for 30 sec. Results: The results showed the gingival index was declined in every group treatment (mouthwash noni fruit extract $5 \%$, chlorhexidine $0.1 \%$ and a mixture of extracts of noni: chlorhexidine (2.5\%: $0.05 \%)$. The differences between each group were not significant $(p>$ 0.05). Conclusion: Despite it give the same effect, the extract of noni fruit should be used as an alternative to mouthwash because it gives the same effect as much as chlorhexidine and it also economical, efficacious and minimal side effects.
\end{abstract}

Key words: Chlorhexidine, Morinda citrifolia L., Noni fruit extract, Gingival index, Mouthwash

\section{INTRODUCTION}

Periodontal disease is one of the most widespread diseases and produces progressive destruction to dental supporting tissues due to bacterial inflammation. ${ }^{1}$ It is an infectious disease in the oral cavity that affecting periodontal tissues such as gingiva, periodontal ligament, cementum and alveolar bone. ${ }^{2,3}$

One of periodontal disease is gingivitis, with clinical sign red gingival, swollen and bleeding easily. ${ }^{1}$ According to data on Badan Litbangkes, ${ }^{4}$ $96.58 \%$ of Indonesian suffering from dental and oral diseases including gingivitis and according to The Annual Report of Padang City Health Office (DKK Padang) ${ }^{5}$ gingivitis is the second most common disease and tooth disorder that visit public health center.

The primary cause of the periodontal disease is a bacterial infection. ${ }^{1}$ The bacteria that led to gingivitis are Streptococcus mutans, Porphyromonas gingivalis, Bacteroides intermedius, Actinobacillus actinomycetemcomitans, Enterococcus faecalis, etc. The periodontal inflammatory disease develops when bacterial proliferation exceeds the threshold of the host resistance and was due to the total effect of plaque flora. ${ }^{6}$

Gingivitis therapy mechanically does in the oral cavity such as brushing teeth and gargling uses an antiseptic mouthwash to decrease the number of colonies of pathogenic bacteria, to reduce the occurrence of plaque and dental caries. ${ }^{7}$ One of the antiseptic mouthwash that usually used was chlorhexidine mouthwash. Chlorhexidine was effectively preventing and controlling gingivitis that could be used as a plaque control agent that showed the best results as an antiseptic effect. ${ }^{8}$ Despite it was effectively as strong antiseptic action, chlorhexidine has side effects such as tooth pigmentation, changes in tasting sensation and the formation of supragingival calculus in long-term use. Other mouthwashes such as povidone iodine in long-term used would give side effects such as iodine sensitivity problems, local erythema, pain, mucosal erosion and major risks associated with thyroid function. ${ }^{8,9,10}$ Various side effects arising from using of chemicals in the mouthwash was so many and significant, so it should take another alternative as a raw material to make a mouthwash with minimal side effects, economical and efficacious. The available alternative was the ingredients from the herb. ${ }^{11}$

One of these herbal ingredients was noni fruit (Morinda citrifolia L.). Previous research has shown that the noni fruit was actively inhibited by Streptococcus mutans in vitro. ${ }^{12,13}$ The results of allergic reactions have been found that the extract of ethanol of noni fruit could inhibit active cutaneous anaphylactic reaction and mastocyte cell degranulation in mice that induced by albumin. ${ }^{14}$ The chloroform fraction of noni fruit extract was also able to increase the phagocytic ability and the number of leukocyte cells. ${ }^{15}$

Noni fruit contains scopoletin, ascubin, alizarin, some anthraquinone substances and saponin 
that act as antibacterial. ${ }^{16,17}$ Scopoletin has been shown to inhibit an active cutaneous anaphylactic reaction (allergic), ${ }^{18}$ increase macrophage activity and the number of leucocyte cells, ${ }^{19}$ decrease production of IgE, ${ }^{20} \mathrm{IL}-4^{21}$ and IL- $10^{22}$ in mice that experiencing type I hypersensitivity reactions.

Therefore, to consider gingivitis as a wide-spreading disease on the community in Indonesia and to overcome it was still used the synthetic drugs with pretty much expensive, thus it needs to find a new drug from natural ingredients with cheap prices, efficient and effective. One of it could be derived from this research, which is an extract of noni fruit.

Based on that circumstances, the objective of this research was doing clinical research that examines the effect of an extract of Morinda citrifoliae fructus L. that given in as a mouthwash to gingival index in gingivitis patient.

\section{MATERIALS AND METHODS}

\section{Place and time}

As a whole, this research was conducted in two months in NovemberDecember 2017. Specifically, the extraction and preparation of characterisation of noni fruit were conducted in three weeks at Laboratory of Sumatera's Biota Faculty of Pharmacy Universitas Andalas. Then to determine the characterisation from noni's extract was conducted in Laboratory of Serology of Faculty of Pharmacy of Universitas Andalas for a week. The examination of mouthwash and the evaluation of mouthwash were conducted in Laboratory of Biomedical of Faculty of Medicine of Universitas Andalas for two weeks. After that, respondents were selected and the gingival index was measured before and after the treatment. It was conducted in Pasar Baru Dental Clinic for two weeks.

\section{Tools and materials}

The tools in this research were the filter paper, funnel, measuring glass (pyrex), analytical scales (Shimadzu, Japan), rotary evaporator (Buchi R-215, Germany), blender, oven (Memmert), furnace, porcelain exchange rate, desiccator, Camag UV lamps $254 \mathrm{~nm}$ and $366 \mathrm{~nm}$, pumpkin measuring (pyrex), mouthwash container, glass mouth, tweezers, periodontal probe, cotton, flashlight, mask and glove.

The materials on this research were noni fruit, ethanol $96 \%$, pure scopoletin, methanol P, silica gel 60 F254, n-hexane, ethyl acetate, methylene blue, sodium benzoate, benzoic acid, tween 80 , sodium saccharin, aqua menthae piperitae, aquades and a mouthwash containing chlorhexidine $0.1 \%$.

\section{Extraction of noni fruit}

Noni fruit cleaned then chopped and dried in the oven at a temperature of $40^{\circ} \mathrm{C}$, then mashed with a blender. Noni fruit powder was macerated with ethanol $96 \%$ and the result of maceration evaporated by using a rotary evaporator to obtain a thick extract. The extract obtained was determined by water content and TLC profile. ${ }^{23}$

\section{Formulation of mouthwash}

Based on pre-lab the best mouthwash was consisting active ingredients, $2 \mathrm{mg}$ blue dye, sodium benzoate $200 \mathrm{mg}$, acidum benzoate $100 \mathrm{mg}$, Tween $80200 \mathrm{mg}$, sodium saccharin $600 \mathrm{mg}$, oleum menthae $2 \mathrm{~mL}$ and aquadest up to $200 \mathrm{~mL}$. This formulation used to make the mouthwash for each treatment. Active substances were divided into 3 group that consist, group I would give an extract of noni fruit $10 \mathrm{~g}$ treatment, group II would give a chlorhexidine $200 \mathrm{mg}$ treatment and group III would give a mixture of noni fruit extract $10 \mathrm{~g}$ and chlorhexidine $20 \mathrm{mg}$

\section{Respondents}

The respondents were 15 students of Universitas Andalas, Padang, Sumatera Barat who had a similar gingival index and divide into 3 groups which every group consists of 5 students for each treatment. The mouthwash was used after brushing teeth in every morning and night for seven consecutive days. For every gargle was used $15 \mathrm{~mL}$ for $30 \mathrm{sec}$. Respondents were not allowed to eat and drink for an hour after rinsing.

\section{Ethical test}

In this research used the human as the subject of study, so it required an ethical test that qualifies to mitigate the treatment gave a bad impact on a human subject in this research. The ethical test was conducted by the Commission of Ethics Faculty of Medicine Universitas Andalas, Padang, Sumatera Barat.

\section{Determination of gingival index}

Assessment of respondent's gingival index based on the method of evaluation of Loe and Sillness Gingival Index. ${ }^{24}$ The four gingival areas of each tooth (facial, mesial, distal and lingual) are assessed for inflammation by scoring in accordance with Table 1 .

\section{Statistical analysis}

The T-test was conducted to determine the degree of differences of each treatment, used SPSS Package 17.0.

\section{RESULTS AND DISCUSSION}

Noni fruit was obtained from Limau Manis, Padang City. It was identified in Herbarium Biology of Faculty of Mathematics and Natural Science of Universitas Andalas. It proved the noni fruit (Morinda citrifolia L.) that obtain was from family (Figure 1).

Noni fruit extract obtained as much as $294.98 \mathrm{~g}$ of 950 grams of dried

Table 1: The value or score of the gingival index according to Loe and Silness.

\begin{tabular}{ll}
\hline Score & Conditions \\
\hline 0 & $\begin{array}{l}\text { Normal gingiva, no inflammation, no discoloration, no bleeding } \\
\text { Mild inflammation, slight discoloration, mild changes in the gingival } \\
\text { surface, no bleeding }\end{array}$ \\
2 & $\begin{array}{l}\text { Medium inflammation, erythema, swelling, bleeding when done } \\
\text { probing or when given pressure }\end{array}$ \\
3 & $\begin{array}{l}\text { Severe inflammation, erythema and severe swelling, tend to occur } \\
\text { spontaneous bleeding, some with ulceration }\end{array}$ \\
\hline
\end{tabular}

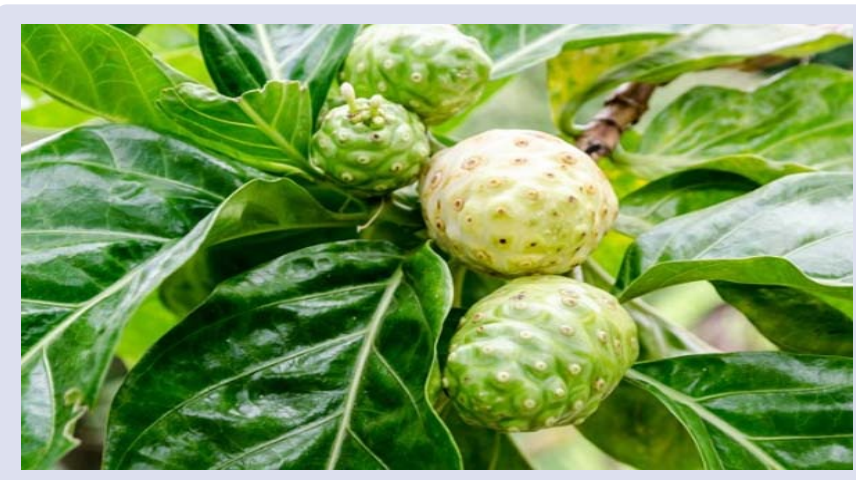

Figure 1: Noni fruit (Morinda citrifolia L.).

*source: Google image (https://bit.ly/2BTGsoJ) 
powder with a rendement of $31.05 \%$. The result of the evaluation of Noni fruit extract obtained a moisture content of $7.33 \%$. The evaluation of rendement and water content has been in according to Depkes RI. ${ }^{23}$

The research proposal was submitted first to the Ethics Commission of the Faculty of Medicine Universitas Andalas Padang to make sure whether this research has been in accordance with research ethics before the examination. The results by the Ethics Commission of Faculty of Medicine of Universitas Andalas Padang showed the study of "Activity of Noni Fruit Extract (Morinda citrifolia L.) in Gingivitis Patients" has fulfilled the research ethics.

Determination of TLC extract profile of noni fruit was obtained Rf extract 0.5 and $\mathrm{Rf}$ of scopoletin comparison were 0.5 . This indicates that an extract of noni fruit contains scopoletin compound, this is seen from the TLC profile in Figure 2.

The analysis effect of extract noni fruits $5 \%$ as a mouthwash was tested against gingival index before treatment (first day) and after treatment (day nine) showed in Table 2. Based on the result of group I which gargle with extract of noni fruit $5 \%$ obtained average gingival index before treatment was $0.50 \pm 0.42$ and after treatment was 0.20 \pm 0.20 . The result of the analysis showed a significant decrease in the gingival index in the gargling group with gargle extract of noni fruit $5 \%(\mathrm{p}<0.05)$. In reducing the gingival index by an extract of noni fruit happened in two mechanisms, that were through anti-inflammatory and antibacterial effect. Furthermore, the decline may also occur due to the biochemical action of the compounds contained from the noni fruit by inhibiting plaque accumulation which is the main cause of gingival inflammation. This is supported by previous studies that suggested the active substances in Morinda citrifolia L. were effective in antibacterial activity. ${ }^{13}$

The use of chlorhexidine $0.1 \%$ as a mouthwash on gingival inflammation for eight days was found could decrease inflammation, it could be seen from the decrease in gingival index value and the results can be seen in Table 3. The results showed that the mean gingival index before treatment was $0.88 \pm 0.24$ and after treatment was $0.43 \pm 0.34$ with $0.1 \%$ chlorhexidine mouthwash. It was a significant decrease in the gingival index after gargling with $0.1 \%$ chlorhexidine $(\mathrm{p}<0.05)$.

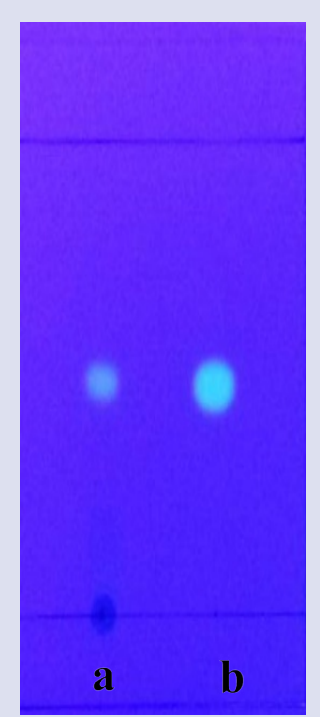

Figure 2: TLC profile of Morinda citrifolia L. extract under UV light $366 \mathrm{~nm}$ with motion phase is $\mathrm{n}$-hexane: ethyl acetate $(1: 1)$ and silica gel F254 for the stationary phase. Description a = extract of noni fruit, $b=$ scopoletin (comparison).
Table 2: The gingival index value of the respondents who had been given an extract of $\mathbf{5 \%}$ noni fruit for eight days.

\begin{tabular}{ccccc}
\hline Respondentts & Pretest & Posttest & Decrease & $\mathrm{p}$ \\
\hline 1 & 0.60 & 0.29 & 0.31 & \\
2 & 0.30 & 0.04 & 0.26 & \\
3 & 1.20 & 0.50 & 0.7 & 0.047 \\
4 & 0.20 & 0.08 & 0.12 & \\
5 & 0.20 & 0.08 & 0.12 & \\
Average & $0.50 \pm 0.42$ & $0.20 \pm 0.20$ & $0.30 \pm 0.24$ & \\
\hline
\end{tabular}

Table 3: The gingival index value of respondents who had been given chlorhexidine $0.1 \%$ rinse for eight days.

\begin{tabular}{ccccc}
\hline Respondents & Pretest & Posttest & Decrease & $\mathrm{p}$ \\
\hline 1 & 1.20 & 0.67 & 0.53 & \\
2 & 1.00 & 0.90 & 0.1 & \\
3 & 0.90 & 0.08 & 0.82 & 0.019 \\
4 & 0.60 & 0.25 & 0.35 & \\
5 & 0.70 & 0.25 & 0.45 & \\
Average & $0.88 \pm 0.24$ & $0.43 \pm 0.34$ & $0.45 \pm 0.26$ & \\
\hline
\end{tabular}

Chlorhexidine was a disquanid derivative and commonly used in the form of gluconate. It has a broad spectrum antibacterial, effective against positive gram and negative gram. Various clinical trials using chlorhexidine mouthwash have been widely practiced and the results show that chlorhexidine decreases the risk of gingivitis and periodontitis. ${ }^{24}$

The study also continued by looking at the effect of a mixture of noni fruit extract with chlorhexidine. with each mixed concentration in group I and II, it was an extract of noni fruit $2.5 \%$ and chlorhexidine $0,1 \%(1: 1)$. The results of the gingival index after used the mix of noni fruit extract and chlorhexidine could be seen in Table 4 . The mixture of noni fruit extract and chlorhexidine was significantly decreased in the gingival index $(\mathrm{p}<0.05)$.

The $t$-test was conducted to compare the three groups of mouthwash, the extract of noni fruit $5 \%$, chlorhexidine $0.1 \%$ and a mixture of an extract of noni fruit $2.5 \%$ : chlorhexidine $0.05 \%(1: 1)$. The result showed there was not significantly different $(p>0.05)$. The $t$-test showed that the three types of mouthwash were equally effective in reducing gingivitis The comparison of gingival index values of the three groups can be seen in Table 5 and Figure 3

Chlorhexidine has been shown to bind bacteria because of the interaction between positive charges of chlorhexidine molecules and negatively charged cell walls. This interaction will increase the permeability of bacterial cell walls that cause cell membrane rupture, the occurrence of cytoplasmic leakage and ultimately lead to death in microorganisms. ${ }^{23}$ The chlorhexidine was better compared to other mouthwashes because it was an attachment to the substance (oral tissue). The bonding with either soft tissue or hard on the mouth causes the chlorhexidine effect to persist for a long time after use..$^{25,26}$

Noni's fruit consist scopoletin that could increase the activities and the capacities of macrophage and also increasing leukosit. ${ }^{20}$ Through the effect of scopoletin on macrophage, it could prohibit the bacteria that cause gingivitis disease more effectively. Scopoletin also could decrease the production of $\mathrm{IL}-4^{21}$ and $\mathrm{IL}-10^{22}$ that made proliferation and differentiation of $\mathrm{T}$ cell lead $\mathrm{Th} 1$ cell that could release cytokines that effect to proliferation and differentiation of monocyte and leukocyte. The extract of noni fruit extract could be used as an alternative to mouthwash because many contain natural ingredients that could inhibit the occurrence of inflammation and kill bacteria that causes plaque and it could be used for maintenance of dental health. 
Table 4: The gingival index values of the respondents who had been given a gargle mixture of $5 \%$ citric fruit extract: chlorhexidine $0.1 \%$ (1 : 1) for eight days.

\begin{tabular}{ccccc}
\hline Respondents & Pretest & Posttest & Decrease & $\mathrm{p}$ \\
\hline 1 & 0.60 & 0.25 & 0.35 & \\
2 & 1.30 & 1.17 & 0.13 & \\
3 & 0.25 & 0.17 & 0.08 & 0.045 \\
4 & 1.10 & 0.625 & 0.475 & \\
5 & 0.30 & 0.20 & 0.1 & \\
Average & $0.71 \pm 0.47$ & $0.48 \pm 0.43$ & $0.23 \pm 0.18$ & \\
\hline
\end{tabular}

Table 5: The result of the analysis of variant (ANOVA) on Gingival index before and after treatment.

\begin{tabular}{cccccc}
\hline & Sum of Squares & df & $\begin{array}{c}\text { Mean } \\
\text { Square }\end{array}$ & F & Sig. \\
\hline Between groups & 0.129 & 2 & 0.064 & 1.234 & 0.326 \\
Within groups & 0.626 & 12 & 0.052 & & \\
$\quad$ Total & 0.755 & 14 & & & \\
\hline
\end{tabular}

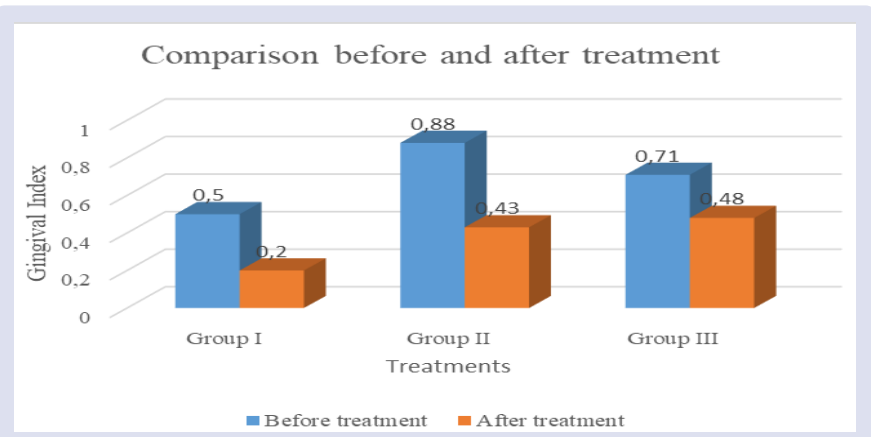

Figure 3: Graphic of comparison between gingival index before and after treatment of each test group.

\section{CONCLUSION}

All mouthwash that used in this research could be used as an antiseptic mouthwash but the extract noni should be used more than another mouthwash because it gives the same effect as chlorhexidine and it also with minimal side effects, economical and efficacious.

\section{ACKNOWLEDGEMENT}

The authors would like to deliver a special appreciation to the Dean Faculty of Pharmacy of Universitas Andalas for the financial support based on DIPA Faculty of Pharmacy's of Universitas Andalas.

\section{CONFLICTS OF INTEREST}

The author(s) declare(s) that there is no conflicts of interest regarding the publication of this article.

\section{ABBREVIATIONS}

Badan Litbangkes: Badan Penelitian dan Pengembangan Kesehatan (Agency of Health Research and Development of Department of Health of Republic of Indonesia); DKK Padang: Dinas Kesehatan Kota Padang (Padang City Health Office); IgE: Immunoglobulin E; IL-4: Interleukin 4; IL-10: Interleukin 10; TLC Profile: Thin-Layer Chromatograpy Profile.

\section{REFERENCES}

1. Newman MG, Takei H, Klokkevold PR, Carranza FA. Carranza's clinical periodontology. Elsevier health sciences; 2011.

2. Pratiwi EW, Praharani D, Arina YM. Inhibition of papaya (Carica papaya L.) leaves extract on adhesion of Porphyromonas gingivalis bacteria to neutrophils. Health Library. 2015;3(2):193.

3. Sapara TU. Effectivity antibacterial of Impatiens balsamina L. leave extract on Porphyromonas gingivalis growth. Pharmacon. 2016;5(4).

4. Agency of health research and development of department of health of republic of Indonesia. 2013. Basic health research. Jakarta: Agency of health research and development of department of health of republic of Indonesia. 2013.

5. Padang city health office. 2013. Annual report. Padang City Health Office. 2013

6. Manson JD, Eley BM. Outline of periodontics. Butterworth-Heinemann; 2000.

7. Wangsarahardja K, Dharmawan OV, Kasim E. Correlation between oral health status and quality life in elderly. Universa Medicina. 2016;26(4):186-94.

8. Marchetti E, Mummolo S, Di Mattia J, Casalena F, Di Martino S, Mattei A, et al. Efficacy of essential oil mouthwash with and without alcohol: A 3-day plaque accumulation model. Trials. 2011;12(1):262

9. Stanley M, Blair KA, Beare PG, editors. Gerontological nursing: Promoting successful aging with older adults. FA Davis Company; 2005

10. Meiner SE. Gerontologic Nursing-E-Book. Elsevier Health Sciences. 2013.

11. Arina Y. Aging process effects on immune system. Maranatha Medical Journal. 2010;3(1).

12. Wang MY, West BJ, Jensen CJ, Nowicki D, Su C, Palu AK, et al. Morinda citrifolia (Noni): A literature review and recent advances in Noni research. Acta Pharmacologica Sinica. 2002;23(12):1127-41.

13. Rifdayani N, Budiarti LY, Carabelly AN. Comparison of bactericidal effect of non fruit (Morinda citrifolia L) $100 \%$ and povidone iodine 1\% on Streptococcus mutans in vitro. Dentistry Journal. 2014;1-6.

14. Aldi Y. Study of noni fruit (Morinda citrifolia L.) for the treatment of Type 1 Hypersensitivity. Speech on 49 $9^{\text {th }}$ Dies Natalis of Pharmacy, University of Andalas, Padang-Indonesia. 2013.

15. Aldi Y, Verawati, Wulandari. Study of immunomodulatory activity of chloroform fraction of noni fruit (Morinda citrifolia L.) on the phagocytotic activity and the leukocyte number of white male mice, The 5th Conference of AASP, Bandung, Indonesia. $16^{\text {th }}-19^{\text {th }}$ June 2011

16. Waha MG. Healthy with noni fruit. MSF Group. Jakarta. Indonesia. 2001;44

17. Levand O, Larson HO. Some chemical constituents of Morinda citrifolia. Planta Medica. 1979;36(06):186-7.

18. Aldi Y, Bakhtiar A, Susanti M. Scopoletin activity on the active cutaneous anaphylactic reaction. In Proceeding of Scientific Congress XVII of Indonesian Pharmacist Association, Makassar-Indonesia. 11 $11^{\text {st }}-12^{\text {nd }}$ December 2010.

19. Aldi Y, Amdani, Bakhtiar A. Effect of scopoletin isolated from noni fruit (Morinda citrifolia L.) on the activity and capacity of peritoneal macrophage in male mice. In proceeding of $2^{\text {nd }}$ national seminar of contemporary pharmaceutical and clinical sciences, Padang-Indonesia. 23 ${ }^{\text {rd }}$ June 2012.

20. Aldi $Y$, Ellyza N, Dian H, Yanwirasti Y, Amri B. Effect of scopoletin from non fruit to the amount of IgE on white male mice with type I hypersensitivity. Indonesian Journal of Natural Product. 2012;8(2):77-83.

21. Aldi $Y$, Yuliandra $Y$, Nasrul E, Yanwirasti $Y$, Handayani D, Bakhtiar A. Decreased interleukin-4 level of type I hypersensitive mice using scopoloetin isolated from noni fruit (Morinda citrifolia L.). Research Journal of Pharmaceutical, Biological and Chemical Sciences. 2015

22. Aldi Y, Handayani D, Bakhtiar A, Wardi A, Yanwirasti, Nasrul E, et al. Effects of scopoletin from noni fruit (Morinda citrifolia L.) to IL-10 levels in male white mice with hypersensitivity type I. Research Journal of Pharmaceutical Biological and Chemical Sciences. 2016:7(4):1404-10.

23. Republic of Indonesia ministry of health. Indonesian herbal pharmacopoeia First edition. Republic of Indonesia ministry of health. Jakarta. 2008

24. Dean JA, Avery DR, McDonald RE. McDonald and avery dentistry for the child and adolescent-E-book. Elsevier Health Sciences. 2010

25. Karpiński TM, Szkaradkiewicz AK. Chlorhexidine-pharmaco-biological activity and application. Eur Rev Med Pharmacol Sci. 2015;19(7):1321-6.

26. Claydon N, Manning CM, Darby-Dowman A, Ridge D, Smith S, Addy M. The effect of polyvinyl pyrrolidone on the clinical activity of $0.09 \%$ and $0.2 \%$ chlorhexidine mouthrinses. Journal of Clinical Periodontology. 2001:28(11):103744. 
GRAPHICAL ABSTRACT

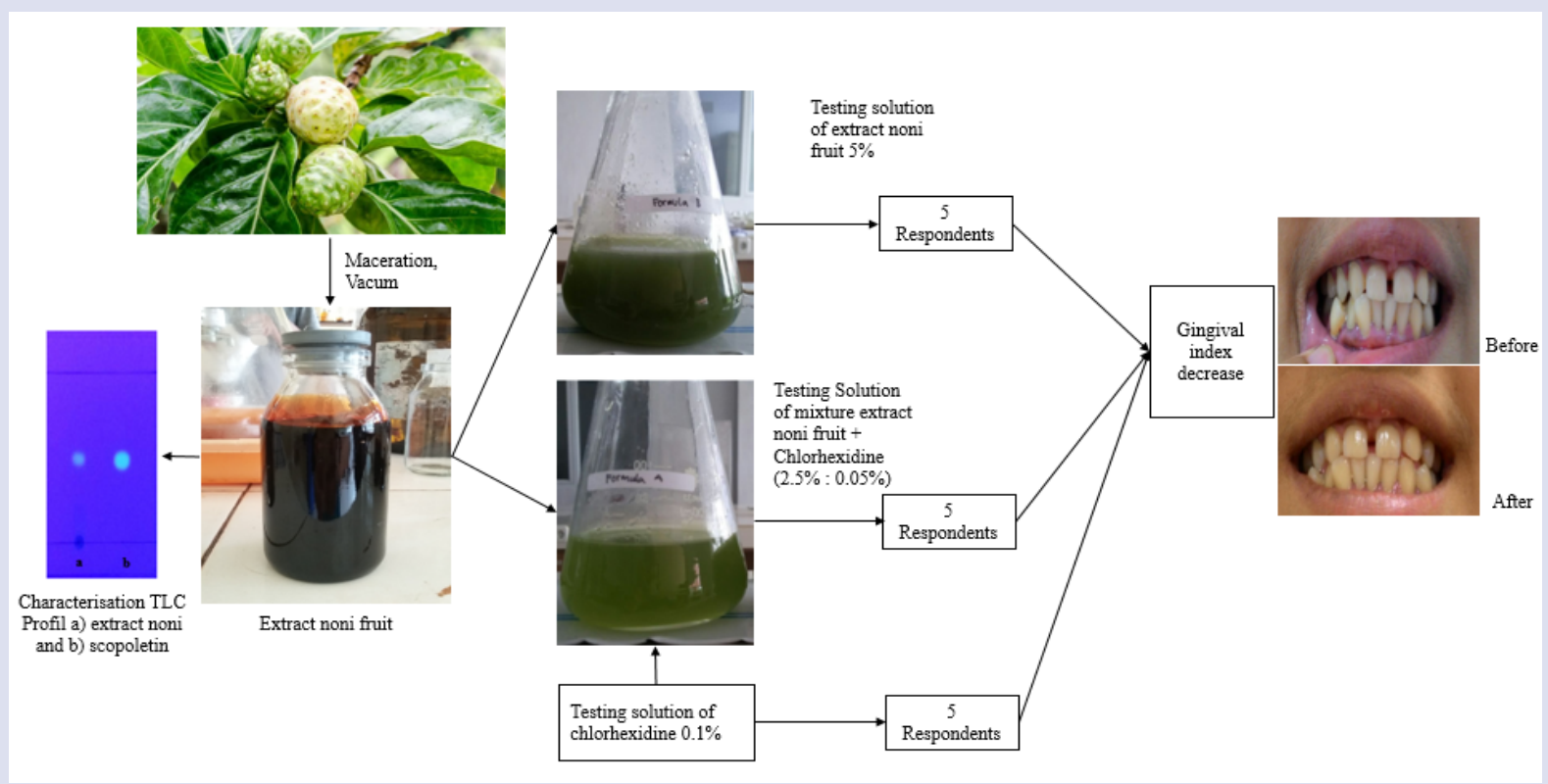

\section{SUMMARY}

Noni fruit reported could be used as anti inflamation active and anti alergi on white male mice and could decreases IgE and IL-4 on alergic white male mice. On this research, it was implemented on gingivitis patients which standarised with $10.9 \%$ rendement in mouthwash form. There were three kind of solutions test that made which are mouthwash with noni fruit extract $5 \%$; chlorhexidine $0.1 \%$; and mixture of extracts of noni: chlorhexidine (2.5\%:0.05\%). The mouthwash was used for 7 days in the morning and at the night sas much as $15 \mathrm{ml}$ and gargling it for 30 second. The result showed that all of mouthwash could decrease gingival index and it was non significantly different $(p>0.05)$.

\section{ABOUT AUTHORS}

- Dr. Drs. Yufri Aldi, M.S.i., Apt.: Currently as a lecturer at the Faculty of Pharmacy, University Andalas. Graduated from Faculty of Pharmacy Universitas Andalas in 1989, then Master Program in 1994 at School of Pharmacy Institut Teknlogi Bandung (ITB Bandung) and Doctoral Program in Department Biomedical, Faculty of Medicine, University Andalas in 2013. The research and expertise are in Farmaco-Immunology. Currently working as an assistant to the First Vice-Rector of Universitas Andalas and Head of the Department Doctoral Programme Pharmacy of Faculty of Pharmacy, Universitas Andalas.

- Hasanatul Khairiyah: She is a student in Faculty of Pharmacy Universitas Andalas who have been involved in assisting in the study of antigingivitis activity using Noni fruit extract.

- Dr. drg. Nila Kasuma, M.Biomed.: Born in Padang at 20 July 1972, completed her study at Universitas Sumatera Utara (1996), and she did the Master of Biomedical Science at Universitas Andalas and Doctoral Programme in Biomedical Sciences (2014) Universitas Andalas. Research interest focuses on gingival.

- Dr. dr. Afriwardi, Sp.KO.: Born in Padang Kandis at 21 April 1967. Completed his education in Medicine Faculty in 1994 at Universitas Andalas, and his Specialist in Sports Medicine in Universitas Indonesia (2001) also the Doctoral Program in Biomedical Science at Universitas Andalas (2010). Currently, he is a lecturer in the Physiology Section of the Faculty of Medicine Universitas Andalas and has been a Dean at the Faculty of Dentistry of Universitas Andalas. His research interest in physiology and biomolecular research.

- Agus Sri Banowo, S.Kp., M.PH.: Currently officiate as Head Department of Mental Health and Community Nursing, Faculty Universitas Andalas. He was born in Semarang 6 October 1969, completed his education in Nursing Programme Faculty of Medicine Universitas Padjadjaran in 2000, and his Master in Master of Public Health Universitas Gadjah Mada in 2015. Expertise in Community Nursing and Communication in Nursing.

Cite this article: Aldi Y, Khairiyah H, Kasuma N, Afriwardi, Banowo AS. The Effect of Noni Fruit Extract (Morinda citrifolia L.) in Gingivitis Patient. Pharmacog J. 2019;11(4):678-82. 